\title{
EFEK GREEN ACCOUNTING TERHADAP MATERIAL FLOW COST ACCOUNTING DALAM MENINGKATKAN KEBERLANGSUNGAN PERUSAHAAN
}

\author{
M. Wahyuddin Abdullah \\ tosir_wahyu@yahoo.com \\ Hernawati Amiruddin \\ Universitas Islam Negeri (UIN) Alauddin Makassar
}

\begin{abstract}
ABSTRAK
This study aims to examine and determine the effect of green accounting on material flow cost accounting in improving company sustainability. The sample used in this study was mining companies listed on the Indonesia Stock Exchange (IDX) during the 2015-2017 period. The total sample consisted of 36 of 4 companies using purposive sampling techniques. The data analysis method uses multiple regression and moderating regression analysis with the absolute difference value approach. Multiple linear regression analysis for the MFCA hypothesis (production costs, factory area, and yield or value of production). The results showed that MFCA (production costs, and yield or production value) had a positive and significant effect on green accounting. MFCA (factory area) has no effect in increasing the company's sustainability. The results of research related to moderating variables indicate that green accounting as a moderating variable influences the relationship between MFCA (yield or value of production) in increasing company sustainability. On the contrary, in the fourth and fifth hypotheses green accounting has no effect on MFCA (production costs, factory area) in increasing company sustainability.
\end{abstract}

Key words: green accounting; material flow cost accounting; company sustainability.

\begin{abstract}
ABSTRAK
Penelitian ini bertujuan untuk menguji dan mengetahui efek green accounting terhadap material flow cost accounting dalam meningkatkan keberlangsungan perusahaan. Sampel yang digunakan dalam penelitian ini adalah perusahaan pertambangan yang terdaftar di Bursa Efek Indonesia (BEI) selama periode 2015-2017. Total sampel berjumlah 36 dari 4 perusahaan dengan menggunakan teknik purposive sampling. Metode analisis data menggunakan regresi berganda dan analisis regresi moderating dengan pendekatan nilai selisih mutlak. Analisis regresi linear berganda untuk hipotesis MFCA (biaya produksi, luas area pabrik, dan hasil atau nilai produksi). Hasil penelitian menunjukkan bahwa MFCA (biaya produksi, dan hasil atau nilai produksi) berpengaruh positif dan signifikan terhadap green accounting. MFCA (luas area pabrik) tidak berpengaruh dalam meningkatkan keberlangsungan perusahaan. Hasil penelitian terkait variabel moderating menunjukkan bahwa green accounting sebagai variabel moderating berpengaruh terhadap hubungan antara MFCA (hasil atau nilai produksi) dalam meningkatkan keberlangsungan perusahaan. Sebaliknya, dalam hipotesis keempat dan kelima green accounting tidak berpengaruh terhadap MFCA (biaya produksi, luas area pabrik) dalam meningkatkan keberlangsungan perusahaan.
\end{abstract}

Kata kunci: green accounting; material flow cost accounting; keberlangsungan perusahaan.

\section{PENDAHULUAN}

Masyarakat mulai sadar betapa pentingnya kelestarian lingkungan untuk kelangsungan hidup manusia dimasa depan. Pen- cemaran lingkungan yang saat ini sudah mencapai pada tahap yang mengkhawatirkan (Aminah dan Noviani, 2014). Dampak yang terjadi pada lingkungan seperti ke- 
bisingan, pencemaran air, tanah dan polusi udara merupakan dampak negatif yang diakibatkan oleh salah satu aktivitas perusahaan yang berlomba-lomba mencari laba (profit) yang setinggi-tingginya tanpa menghiraukan dampak pada lingkungan. Namun pembangunan industri juga sebenarnya memiliki dampak positif dapat menyerap tenaga kerja, meningkatkan produktifitas ekonomi, dan dapat menjadi aset pembangunan nasional maupun daerah (Winarno, 2016). Akan tetapi, kenyataannya selama puluhan tahun praktik bisnis dan industri korporasi Indonesia cenderung tidak ada respon terhadap kepedulian lingkungan hidup. Masyarakat yang sejak awal telah miskin, kenyataannya yang miskin tetap miskin, bahkan semakin miskin karena masyarakat mengeluarkan biaya tambahan untuk biaya kesehatan akibat lingkungan hidup mereka sudah tercemar limbah aktivitas perusahaan.

Pemanfaatan yang mereka lakukan terhadap alam sering kali tidak diiringi dengan usaha pelestarian. Keserakahan dan perlakuan buruk sebagian manusia terhadap alam justru mengakibatkan kerusakan dan kesengsaraan kepada manusia itu sendiri. Kerusakan terjadi di darat dan di laut seperti banjir, tanah longsor, kekeringan, pencemaran air dan udara. Maka sudah sebuah keharusan dalam menjaga lingkungan. Tarmizi et al. (2012) perkembangan dunia usaha menjadi semakin luas, semakin banyak pabrik-pabrik dan perusahaan yang didirikan untuk melakukan aktivitasnya yaitu memproduksi barang mentah maupun barang setengah jadi atau barang jadi. Perusahaan dalam melakukan aktivitasnya menggunakan sumber daya yang tersedia untuk mencapai tujuannya, dalam mencapai tujuan tersebut perusahaan selalu berinteraksi dengan lingkungan.

Isu lingkungan dan sosial yang berdampak negatif akan menyebar dan dapat diakses dengan mudah menggunakan teknologi informasi saat ini. Hal ini tentu memaksa kegiatan bisnis perusahaan terhadap isu lingkungan. Bentuk penyesuaian kegiatan bisnis perusahaan tehadap isu lingkungan adalah akuntansi lingkungan atau green accounting. Selama ini laporan keuangan belum mampu untuk menghadirkan informasi pelaporan aktivitas pemberdayaan lingkungan. Green accounting merupakan suatu upaya untuk menghubungkan kepentingan ekonomi perusahaan dan pelestarian lingkungan (Kusumaningtias, 2013). Green Accounting dianggap alat penting untuk memahami aspek-aspek yang berpengaruh dari alam lingkungan yang berhubungan dengan perekonomian (Farouk et al., 2012). Green Accounting merupakan bagian dari akuntansi lingkungan yang mengkombinasikan manfaat lingkungan dan biaya kedalam pengambilan keputusan. Green Accounting dipengaruhi dan mempengaruhi yang ada disekitar perusahaan itu berdiri.

Perusahaan saat ini dituntut untuk meningkatkan dan memperbaiki kinerjanya yaitu dengan cara meningkatkan produktivitasnya. Produktivitas dapat diukur dengan membandingkan output dan input selama proses produksi. Dalam hal ini perusahaan dituntut untuk memperhatikan selera konsumen dangan meningkatkan kualitas dan kuantitas produksinya. Dalam hal peningkatan produksi, perusahaan banyak mengalami permasalahan yang timbul pada dimensi keberlanjutan perusahaan yaitu ekonomi, teknologi, sosial, dan lingkungan mulai dari level efisiensi dan efektifitas biaya produksi juga proses produksi limbah. Perusahaan dalam proses produksinya harus mampu untuk mengembangkan konsep berkelanjutan dan industri ramah lingkungan yang terintegrasi, menyeluruh, dan efisien. Green Accounting merupakan konsep dimana perusahaan dalam proses produksinya mengutamakan efisiensi dan efektifitas penggunaan sumber daya secara berkelanjutan sehingga mampu menyelaraskan pembangunan perusahaan dengan fungsi lingkungan hidup serta dapat memberi manfaat bagi masyarakat. Praktik akuntansi lingkungan di Indonesia sampai saat 
ini belumlah efektif. Cepatnya tingkat pembangunan di masing-masing daerah dengan adanya otonomi ini terkadang mengesampingkan aspek lingkungan yang disadari atau tidak pada akhirnya akan menjadi penyebab utama terjadinya permasalahan lingkungan (Susilo dan Astuti, 2014). Perusahaan dituntut tidak hanya mengutamakan pemilik dan manajemen, tetapi juga seluruh pihak yang terkait, seperti karyawan, konsumen, serta masyarakat dan lingkungan. Hal ini karena keberadaan perusahaan tidak terlepas dari kepentingan dari berbagai pihak. Siregar et al. (2013) di Indonesia, sekitar 15-20 persen dari limbah dibuang dengan baik, akan tetapi sisanya dibuang ke sungai yang tentunya akan menimbulkan masalah banjir. Selain banjir, masalah yang ditimbulkan oleh limbah pabrik adalah pencemaran air sungai yang mengakibatkan kualitas air bersih pun memburuk. Sekitar 85 persen kota-kota kecil dan 50 persen kota-kota besar membuang sampah mereka di tempat terbuka. Sekitar 75 persen limbah perkotaan dapat terurai dan dapat digunakan sebagai kompos dan biogas.

Fakoya (2014) perdebatan tentang efisiensi sumber daya terutama yang berkaitan dengan pengurangan dan pengelolaan limbah tidak hanya menjadi perhatian bagi para ilmuwan dan aktivis lingkungan hidup, tetapi juga pihak manajemen perusahaan. Proses produksi suatu barang mulai dari pengambilan bahan baku sampai ke pembuangan suatu produk setelah dikonsumsi (digunakan) tidak merusak lingkungan (Idris, 2012). Apalagi jika perusahaan mampu untuk merinci biaya lingkungan tersebut. Hal ini agar perusahaan tidak menggeneralisir biaya-biaya tidak langsung termasuk biaya lingkungan kedalam biaya overhead sehingga membuatnya tersembunyi dan manajer kesulitan untuk menelusuri dan mengendalikan biaya tersebut (Descalu et al., 2010).

Biaya-biaya terkait lingkungan umumnya adalah biaya pengolahan limbah, pembuangan limbah, pembangunan instalasi, biaya kepada pihak ketiga, biaya perizinan dan sebagainya. Dalam upaya untuk berkontribusi pada masalah pengurangan limbah dari perspektif yang berbeda, akuntansi manajemen kontemporer mengembangkan alat pengumpulan untuk kuantifikasi limbah tertentu, yaitu Material Flow Cost Accounting (MFCA) untuk memberikan informasi secara keuangan dan non-keuangan dalam rangka mendukung keputusan pengurangan limbah oleh para manajer. Material Flow Cost Accounting (MFCA) pertama kali dikembangkan di Jerman. Selanjutnya, dalam beberapa tahun belakangan ini, konsep MFCA mengalami berbagai penyempurnaan dalam penerapannya di Jepang, dan menjadi teknik pengelolaan yang cukup unik, yang memberikan dampak signifikan terhadap pengurangan biaya dan peningkatan kualitas. Material flow cost accounting (MFCA) adalah alat manajemen yang membantu organisasi untuk lebih memahami konsekuensi lingkungan dan keuangan potensial dari materi dan praktik energi dan berusaha memperbaikinya melalui perubahan dalam praktiknya.

Penelitian terdahulu tentang MFCA juga telah dilakukan oleh Kourilova dan Plevkova (2013) dengan studi tentang model deteksi MFCA dengan akuntansi lingkungan. Hasil penelitiannya menunjukkan bahwa pada saat bersamaan, MFCA dapat dijadikan model untuk mendeteksi produksi dan bisnis perusahaan. Nakajima, Kimura, dan Wangner (2014) dari hasil penelitian menyatakan pentingnya meningkatkan kesadaran isu-isu lingkungan dalam kelancaran berbagi informasi, karena pada saat bersamaan kerangka kerja suatu perusahaan akan terbentuk dan efisiensi sumber daya juga terbentuk. Tajelawi dan Garbharran (2015) menyatakan bahwa MFCA terbukti menyediakan informasi limbah terbaik untuk memungkinkan manajer perusahaan membuat keputusan manajemen limbah yang terinformasi, sehingga keberlanjutan perusahan tercapai. Sejalan dengan penelitian Loen (2018) tentang penerapan green accounting dan material flow cost accounting 
yang membuktikan bahwa material flow cost accounting dan green accounting dapat meningkatkan keberlangsungan suatu perusahaan. Marota (2017) dalam penelitiannya tentang material flow cost accounting atau sering disebut MFCA yang menggunakan biaya produksi, luas area pabrik produksi dan nilai atau hasil produksi sebagai variabel dalam MFCA, menunjukkan bahwa MFCA berpengaruh dalam keberlangsungan perusahaan. Berdasarkan uraian diatas penelitian mengemukakan rumusan penelitian antara lain: 1) Apakah MFCA (biaya produksi) berpengaruh dalam meningkatkan keberlangsungan perusahaan? 2) Apakah MFCA (luas area pabrik produksi) berpengaruh dalam meningkatkan keberlangsungan perusahaan? 3) Apakah MFCA (hasil atau nilai produksi) berpengaruh dalam meningkatkan keberlangsungan perusahaan? 4) Apakah green accounting berdampak dalam meningkatkan pengaruh MFCA (biaya produksi) terhadap keberlangsungan perusahaan? 5) Apakah green accounting berdampak dalam meningkatkan pengaruh MFCA (luas area pabrik produksi) terhadap keberlangsungan perusahaan? 6) Apakah green accounting berdampak dalam meningkatkan pengaruh MFCA (hasil atau nilai produksi) terhadap keberlangsungan perusahaan? Tujuan penelitian ini yaitu untuk mengetahui pengaruh MFCA (biaya produksi, luas area pabrik dan hasil atau nilai produksi) dalam meningkatkan keberlangsungan perusahaan, dan untuk mengetahui green accounting berdampak dalam meningkatkan pengaruh MFCA (biaya produksi, luas area pabrik dan hasil atau nilai produksi) terhadap keberlangsungan perusahaan.

\section{TINJAUAN TEORETIS Stakeholder Theory}

Stakeholder theory merupakan salah satu teori utama yang banyak digunakan untuk mendasari penelitian tentang sustainability development. Stakeholder dibagi menjadi dua, yaitu stakeholder internal yang terdiri dari pemilik, manajemen, dan karyawan; dan stakeholder eksternal yang terdiri dari pemerintah, masyarakat, lingkungan dan pemangku kepentingan masa depan (Hernadi, 2012). Sedangkan yang termasuk ke dalam stakeholder sekunder adalah media dan pihak-pihak yang berkepentingan dengan cakupan yang lebih luas (Cohen et al., 2009).

Hubungan perusahaan dengan stakeholder dibangun berdasarkan konsep kebermanfaatan yang membangun kerjasama untuk bisa membangun kesinambungan usaha perusahaan. Mengabaikan kepentingan para pemangku kepentingan dapat mencemari citra publik perusahaan, yang tidak baik akan mempengaruhi kinerja keuangan perusahaan. Stakeholder memiliki harapan yang berbeda-beda terhadap perusahaan, untuk mengejar harapan tersebut stakeholder dapat memberikan tekanan kepada perusahaan secara langsung maupun tidak langsung dalam melakukan pengungkapan lingkungan (Ghomi dan Leung, 2013). Munculnya teori stakeholders sebagai paradigma dominan semakin menguatkan konsep bahwa perusahaan bertanggung jawab tidak hanya kepada pemegang saham melainkan juga terhadap para pemangku kepentingan atau stakeholder (Maulida dan Adam, 2012).

\section{Legitimacy Theory}

Legitimacy theory dan stakeholders theory merupakan teori yang menjelaskan motivasi para manajer atau organisasi untuk melakukan pengungkapan laporan berkelanjutan. Jika teori stakeholders dimotivasi oleh pertanggungjawaban kepada para pemang$\mathrm{ku}$ kepentingan, maka teori legitimasi menggunakan motivasi untuk mendapatkan pengesahan atau penerimaan dari masyarakat (Laan, 2009). Lindawati dan Puspita (2015) legitimasi dari stakeholders sangat penting bagi perusahaan karena dengan adanya legitimacy gap memiliki potensi besar terjadinya protes dari stakeholders terhadap perusahaan yang berdampak pada eksistensi perusahaan dan mengganggu stabilitas operasional dan berakhir pada profitabilitas. Teori legitimasi merupakan salah satu teori 
yang mendasari insentif entitas yang dengan sukarela mengungkalaapkan laporan pertanggungjawaban sosial dan lingkungan (Luo et al., 2013; Ahmad dan Hossain, 2015). Legitimasi dari masyarakat adalah sumber daya operasional yang paling penting bagi perusahaan karena hal ini terkait dengan going concern (keberlangsungan perusahaan) (Tarigan dan Semuel, 2014). Pendekatan legitimasi dalam green accounting terkait keberlangsungan suatu entitas, dalam hal ini dapat dikatakan sebagai bentuk upaya untuk memberikan transparansi informasi yang diungkapkan tidak hanya berupa informasi keuangan perusahaan saja, tetapi perusahaan juga diharapkan mengungkapkan informasi mengenai dampak-dampak sosial dan lingkungan hidup yang diakibatkan oleh aktivitas-aktivitas perusahaan.

\section{Green Accounting}

Green accounting merupakan akuntansi yang di dalamnya mengidentifikasi, mengukur, menilai, dan mengungkapkan biayabiaya terkait dengan aktivitas perusahaan yang berhubungan dengan lingkungan (Aniela, 2012). Green accounting merupakan penggabungan informasi manfaat dan biaya lingkungan kedalam macam-macam praktik akuntansi dan penggabungan biaya lingkungan kedalam keputusan bisnis (Amiruddin, 2012). Akuntansi lingkungan (green accounting) memberikan laporan bagi pihak internal dan eksternal perusahaan. Apabila pelaporan akuntansi lingkungan bersifat mandatory, akuntabilitas sosial perusahaan akan meningkat (Setiawan, 2016). Tujuan dari akuntansi lingkungan sebagai sebuah alat manajemen lingkungan dan sebagai alat komunikasi dengan stakeholder dan untuk meningkatkan jumlah informasi relevan yang dibuat bagi mereka yang memerlukan atau dapat menggunakannya (Idris, 2012), sehingga dapat mengetahui kegiatan perusahaan dalam upaya menangani pencemaran lingkungan serta kewajiban perusahaan atas masalah. Perusahaan dengan green accounting yang baik tidak hanya mengungkapkan mengenai kepedulian perusahan terhadap lingkungan tetapi juga mengenai kualitas produk, keamanan produk, tanggung jawab sosial perusahaan terhadap masyarakat sekitar, hingga kepedulian perusahaan terhadap keselamatan dan kesejahteraan tenaga kerjanya. Perusahaan yang peduli dengan kinerja lingkungannya tersebut berarti telah menerapkan corporate social responsibility dengan sebagaimana semestinya terbukti dengan tinggi kepedulian lingkungan dan sosial yang tinggi (Rakhiemah dan Dian, 2009). Tujuan dikembangkannya green accounting yaitu untuk mendorong pertanggung jawaban perusahaan dan meningkatkan transparansi lingkungan, membantu entitas dalam menetapkan strategi untuk menanggapi isu lingkungan hidup dalam konteks hubungan entitas dengan masyarakat dan terlebih dengan kelompok-kelompok penggiat (activist) atau penekan (pressure group) terkait isu lingkungan, memberikan citra yang lebih positif sehingga entitas dapat memperoleh dana dari kelompok dan individu "hijau", seiring dengan tuntutan etis dari investor yang semakin meningkat, mendorong konsumen untuk membeli produk hijau sehingga entitas memiliki keunggulan pemasaran yang lebih kompetitif dibandingkan entitas yang tidak melakukan pengungkapan, menunjukkan komitmen entitas terhadap usaha perbaikan lingkungan hidup, mencegah opini negatif publik mengingat perusahaan yang berusaha pada area yang berisiko tidak ramah lingkungan pada umumnya akan menerima tantangan dari masyarakat.

\section{Material Flow Cost Accounting}

MFCA merupakan alat kunci dari pendekatan manajemen disebut sebagai flow management yang bertujuan secara khusus untuk mengelola proses manufaktur yang berkaitan dengan aliran material, energi, dan data sehingga proses manufaktur dapat lebih efisien dan sesuai dengan target yang ditetapkan (Hyrslova et al., 2011, Viere et al., 2011, Jasch 2009). Keuntungan dari penggunaan model MFCA adalah dapat meningkatkan laba dan produktivitas (internal) 
serta mengurangi dampak negatif kelingkungan (eksternal) yang selanjutnya berkontribusi dalam pengembangan keberkelanjutan perusahaan (corporate sustainable development).

Material Flow Cost Analysis (MFCA) adalah salah satu alat utama untuk pengelolaan akuntansi lingkungan dan mengajukan peningkatan transparansi dari praktek penggunaan bahan baku dari pengembangan model aliran bahan baku yang bisa menelusuri dan menghitung aliran dan persediaan bahan baku dalam sebuah organisasi secara fisik dan unit moneter. MFCA bisa digunakan disemua jenis industri yang menggunakan bahan baku dan energi, semua jenis dan ukuran, dengan atau tanpa tempat sistem pengelolaan lingkungan. Konsep utama MFCA didasarkan pada masukan (bahan, energi, air, dan input lainnya) dan keluaran (produk utama atau produk sampingan, limbah, limbah cair, emisi) ditentukan dalam pusat kuantitas, dan perhitungan dilakukan sehubungan dengan biaya material, energi, dan sistem yang dikeluarkan untuk produk dan kerugian material.

Dalam upaya perusahaan untuk berkontribusi pada masalah pengurangan limbah, terdapat beberapa pendekatan pengelolaan limbah dan pemanfaatan bahan baku dari sumber limbah diantaranya adalah dengan mengunakan analisis pinch, pengembangan model matematika untuk pengelolaan bahan baku dan produk, sintesis pertukaran jaringan masa reaktif, dan metode grafis untuk pembuangan limbah (Mahmoudi et al. 2017). Istilah produk mengacu pada produk yang dipindahkan ke tahap pembuatan berikutnya (pusat kuantitas) yang sesuai dan meninggalkan perusahaan sebagai produk akhir. Dalam hal MFCA, istilah kerugian material tidak hanya terlihat dalam arti sempit, namun mengacu pada semua bahan, energi, dan sumber daya ekonomi yang diinvestasikan (Hyrslova et al. 2011).

\section{Keberlangsungan Perusahaan}

Bare (2011) mengungkapkan bahwa terdapat lima elemen bagi organisasi perusahaan dalam pengembangan lingkungan yang berkelanjutan yaitu keberlanjutan dalam ekonomi, indikator sosial, analisis lingkungan, indikator keberlanjutan yang diseleksi secara independen serta material dan sumber daya yang digunakan. Keberlanjutan suatu perusahaan menjadi faktor pengembangan untuk memenuhi kebutuhan saat ini tanpa mengorbankan kemampuan dimasa yang akan datang untuk memenuhi kebutuhannya itu sendiri (Lynch, 2011). Keberlangsungan hidup suatu perusahaan bergantung pada keuntungan (profit) yang diperolehnya. Keuntungan inilah yang kemudian menjadi tujuan utama didirikannya suatu perusahaan.

Keberlangsungan perusahaan merupakan seberapa lama perusahaan dapat bertahan terhadap perkembangan dunia industri. Kawasan industri yang berkelanjutan adalah perencanaan pengembangan yang mengacu pada konsep sustainable development, yakni pengembangan yang mengintegrasikan aspek ekonomi, sosial dan lingkungan (Agustia, 2010). Pada umumnya, semakin besar keuntungan yang diperoleh suatu perusahaan maka semakin terjamin pula keberlangsungan hidup perusahaan tersebut.

Oleh karena itu, apabila suatu perusahaan melakukan berbagai usaha untuk meningkatkan keuntungannya, misalnya dengan peningkatan produktivitas dan efisiensi biaya. Peningkatan produktivitas bisa diperoleh dengan memperbaiki manajemen kerja melalui penyederhanaan proses, pengurangan aktivitas yang tidak efisien, peng hematan waktu proses dan pelayanan, serta penggunaan material sehemat mungkin dan pemangkasan biaya serendah mungkin (Rahmayanti, 2014).

\section{Pengaruh Material Flow Cost Accounting (biaya produksi) dalam Meningkatkan Keberlangsungan Perusahaan}

Perusahaan selalu memiliki masalah dalam persaingan sehingga perusahaan 
harus selalu melakukan inovasi dalam mutu barang dan layanan serta efisiensi dalam menekan biaya produksi sehingga harga penjualan produk tetap dapat bersaing (Putranto, 2017). Penelitian Rieckhof et al., (2015) juga menunjukkan bahwa MFCA akan mendorong strategi perusahaan menuju atau kearah efisiensi sumber daya kedepannya. Kecenderungan baru sistem layanan produk yang berpotensi memperkecil dampak lingkungan baik dari produksi maupun konsumsi. Dalam hal ini sistem layanan produk yang sukses memerlukan infrastruktur masyarakat, struktur manusia dan tata letak organisasi yang berbeda agar berfungsi secara berkelanjutan.

Alfian et al. (2020) menunjukkan bahwa penerapan MFCA di PT Unipres Indonesian diawali dengan identifikasi proses produksi suku cadang kendaraan berupa input, aliran produksi, dan ouput yang dihasilkan. Input produksi yaitu kuantitas dan kualitas material produksi berupa gulungan baja (coil), selain bahan bakar atau energi yang digunakan dan sumber daya manusia yang bertanggungjawab pada proses produksi. Aliran produksi adalah aliran material produksi pada setiap line di area pabrik yang menjadi quantity center. Output produksi dalam konsep MFCA adalah produksi utama berupa suku cadang kendaraan "Seal Inner"dan limbah yang dihasilkan berupa scrapt atau potongan-potongan baja sisa hasil produksi. Hasil penerapan MFCA di PT Unipres Indonesia dapat diketahui dari besaran biaya kerugian material yaitu sebesar Rp 650.325 dari pemakaian energi, sumber daya manusia dan biaya overhead lainnya per satu produk suku cadang yang diproduksi. PT Unipres Indonesia memperlakukan limbah sisa hasil produksi tersebut dengan melakukan penjualan scrapt atau sisa hasil produksi kepada pihak ketiga sehingga atas penjualan scrapt atau sisa hassil produksi tersebut dapat menambah pemasukan perusahaan dan membantu berkontribusi terhadap kinerja keuangan.

Penelitian sebelumnya juga telah dilakukan oleh Marota, et al. (2015) yang meneliti tentang perancangan dan penerapan MFCA untuk peningkatan keberlanjutan perusahaan. Tempat penelitian pada perusahaan minyak kelapa sawit CPO. Hasilnya menunjukkan pengaruh yang signifikan antara penerapan MFCA dan keberlanjutan perusahaan. Hasil pe- nelitian Kourilova dan Plevkova (2013) ten- tang model deteksi MFCA dengan akuntansi lingkungan menunjukkan bahwa MFCA dapat digunakan sebagai model untuk mendeteksi biaya produksi dan bisnis sebuah perusahan yang dapat meningkatkan keberlangsungan perusahaan. Maka hipotesis pertama yang diajukan:

$\mathrm{H}_{1}$ : MFCA (biaya produksi) berpengaruh dalam meningkatkan keberlangsungan perusahaan

\section{Pengaruh MFCA (Luas Area Pabrik Pro- duksi) dalam Meningkatkan Keberlangsu- ngan Perusahaan}

Penelitian Tajelawi dan Garbharran (2015) menyatakan bahwa MFCA terbukti menyediakan informasi limbah terbaik untuk memungkinkan manajer perusahaan membuat keputusan manajemen limbah yang terinformasi, sehingga keberlanjutan perusahan tercapai. MFCA dapat digunakan untuk meningkatkan transparansi aliran material (material flow) dan penggunaan energi, serta biaya yang terkait dan dampak lingkungan, dan untuk mendukung keputusan perusahaan melalui informasi yang diperoleh melalui MFCA. Marota et al. (2015) yang meneliti tentang perancangan dan penerapan MFCA untuk meningkatkan keberlanjutan perusahaan. Hasilnya menunjukkan bahwa pengaruh yang signifikan antara penerapan MFCA dan keberlanjutan perusahaan.

Keberlanjutan suatu perusahaan menjadi faktor pengembangan untuk memenuhi kebutuhan saat ini tanpa mengorbankan kemampuan di masa yang akan datang untuk memenuhi kebutuhannya itu sendiri (Lynch, 2011). Penelitian lain juga mengungkapkan bahwa semakin luas lahan atau area pabrik maka semakin besar pula jumlah 
produk yang dapat di hasilkan oleh sebuah perusahaan (Danny dan Marhaeni, 2017), maka hipotesis dari penelitian ini beranggapan bahwa:

$\mathrm{H}_{2}$ : MFCA (luas area pabrik produksi) berpengaruh dalam meningkatkan keberlangsungan perusahaan

Pengaruh MFCA (Hasil atau Nilai Produksi) dalam Meningkatkan Keberlangsungan Perusahaan

MFCA merupakan alat kunci dari pendekatan manajemen disebut sebagai flow management yang bertujuan secara khusus untuk mengelola proses manufaktur yang berkaitan dengan aliran material, energi, dan data sehingga proses manufaktur dapat lebih efisien dan sesuai dengan target yang ditetapkan (Hyrslova et al. 2011 dan Viere et al. 2011). Hasil Penelitian Putra (2012) nilai produksi terhadap penyerapan tenaga kerja pada industri mebel di Kecamatan Pedurungan Kota Semarang menunjukkan bahwa ada pengaruh terhadap penyerapan tenaga kerja pada industri mebel di Kecamatan Pedurungan Kota Semarang.

Hasil penelitian Kourilova dan Plevkova (2013) tentang model deteksi MFCA dengan akuntansi lingkungan menunjukkan bahwa MFCA dapat digunakan sebagai model untuk mendeteksi produksi dan bisnis sebuah perusahaan. Keuntungan dari penggunaan model MFCA adalah dapat meningkatkan laba dan produktivitas (internal) serta mengurangi dampak negatif kelingkungan (eksternal) yang selanjutnya berkontribusi dalam pengembangan keberkelanjutan perusahaan (corporate sustainable development), maka hipotesis dari penelitian ini beranggapan bahwa:

$\mathrm{H}_{3}$ : MFCA (Hasil atau Nilai Produksi) Berpengaruh dalam Meningkatkan Keberlangsungan Perusahaan

Dampak Green accountting dalam meningkatkan pengaruh MFCA (biaya produksi, luas area pabrik dan hasil atau nilai produksi) terhadap keberlangsungan perusahaan
Green Accounting mempunyai manfaat bagi internal perusahaan untuk memberikan laporan mengenai pengelolaan internal, yaitu keputusan manajemen mengenai pemberian harga, pengendalian biaya overhead, penganggaran modal (capital budgeting) dan biaya produksi. Kegiatan produksi yang bermanfaat dengan mengurangi dampak lingkungan, menghemat konsumsi sumber daya dan biaya secara simultan (Setiawan, 2016). Perusahaan yang memperhatikan lingkungan akan mendapatkan legitimacy dari masyarakat.

Kourilova dan Plevkova (2013) mengadakan studi tentang model deteksi MFCA dengan akuntansi lingkungan. Hasil studi menunjukkan bahwa MFCA dapat dijadikan model untuk mendeteksi produksi dan bisnis perusahaan sekaligus. MFCA terdiri beberapa variabel yang mewakli diantaranya luas lahan. Bare (2011) menyebutkan bahwa terdapat lima elemen bagi organisasi perusahaan dalam pengembangan lingkungan yang berkelanjutan yaitu keberlanjutan dalam ekonomi, indikator sosial, analisis lingkungan, indikator keberlanjutan yang diseleksi secara independen serta material dan sumber daya yang digunakan. Dampak negatif yang paling sering muncul ditemukan dalam setiap adanya penyelenggaraan operasional usaha perusahaan adalah polusi udara, limbah produksi, kesenjangan sehingga MFCA hadir untuk menurunkan biaya melalui penurunan limbah, yang nantinya akan mengarah keperkembangan produktivitas suatu perusahaan.

Metode MFCA yang berkaitan dengan aliran material, energi, dan data sehingga proses manufaktur dapat lebih efisien dan sesuai dengan target yang ditetapkan. Harus diketahui berapa yang digunakan, berapa yang menjadi produk akhir dan berapa yang menjadi limbah. Informasi fisik dibutuhkan oleh manajemen untuk menentukan tingkat dampak lingkungan yang dihasilkan sehingga dapat dikendalikan. Hasil penelitian Marota (2017) menunjukkan bahwa MFCA dengan variabel biaya produksi, luas area, 
hasil produksi berpengaruh terhadap keberlangsungan suatu perusahaan. Penelitian Loen (2018) menunjukkan bahwa MFCA berpengaruh positif terhadap keberlangsungan perusahaan.

Green accounting sangat bergantung kepada karakteristik perusahaan didalam memahami permasalahan lingkungan hidup yang akan mengarahkan perusahaan didalam kebijakannya terutama terkait dengan keselamatan lingkungan hidup (Astuti, 2012). Setiawan (2013) mengungkapkan bahwa perhatiaan terhadap lingkungan merupakan elevator bisnis dalam memeperoleh laba jangka panjang. Green accounting akan berfungsi dengan baik sebagai alat bagi organisasi untuk memenuhi tanggung jawab lingkungan perusahaan atas akuntabilitas kepada stakeholder dan secara tidak langsung sebagai sarana untuk evaluasi yang tepat dalam kegiatan pelestarian lingkungan (Rustika, 2011).

Green accounting merupakan bagian dari akuntansi lingkungan yang mengkombinasikan manfaat lingkungan dan biaya kedalam pengambilan keputusan dalam MFCA juga terkait biaya-biaya lingkungan umumnya adalah biaya pengolahan limbah, pembuangan limbah, pembangunan instalasi, biaya kepada pihak ketiga, biaya perizinan. Hasil penelitian Loen (2018) menunjukkan bahwa green accounting berpengaruh positif terhadap sustainable development. Keuntungan dari penggunaan model MFCA adalah dapat meningkatkan laba dan produktivitas (internal) serta mengurangi dampak negatif ke lingkungan (eksternal) yang selanjutnya berkontribusi dalam pengembangan keberkelanjutan perusahaan (corporate sustainable development), maka hipotesis dari penelitian ini beranggapan bahwa:

$\mathrm{H}_{4}$ : Green accountting berdampak dalam meningkatkan pengaruh MFCA (biaya produksi) terhadap keberlangsungan perusahaan.

$\mathrm{H}_{5}$ : Green accounting berdampak dalam meningkatkan pengaruh MFCA (luas area pabrik produksi) terhadap keberlangsungan perusahaan

$\mathrm{H}_{6}$ : Green accounting berdampak dalam meningkatkan pengaruh MFCA (hasil atau nilai produksi) terhadap keberlangsungan perusahaan

\section{METODE PENELITIAN}

\section{Jenis Penelitian}

Penelitian ini merupakan jenis penelitian kuantitatif dimana metode penelitian ini berlandaskan pada filsafat positivism (Sugiyono 2012: 260). Adapun pendekatan penelitian ini menggunakan pendekatan deskriptif. Pendekatan deskriptif merupakan penelitian terhadap masalah-masalah yang berupa fakta-fakta saat ini dari suatu populasi dengan tujuan untuk menjawab hipotesis yang bekaitan dengan current status dari subjek yang diteliti.

\section{Populasi dan Sampel}

Populasi dalam penelitian ini adalah perusahaan-perusahaan pertambangan yang terdaftar di Bursa Efek Indonesia pada tahun 2015-2017, dengan jumlah perusahaan pertambangan sebanyak 45 dengan kurung waktu penelitian selama tiga (3) tahun dengan perhitungan pertriwulan.

Sampel dipilih berdasarkan kriteria tertentu sehingga dapat mendukung penelitian ini. Kriteria sampel yang digunakan dalam penelitian ini adalah: 1) Perusahaan pertambangan yang terdaftar pada Bursa Efek Indonesia yakni dari tahun 2015 sampai 2017. 2) Perusahaan pertambangan yang menerbitkan laporan keuangan yang lengkap selama tahun pengamatan, yakni dari tahun 2015 sampai 2017. 3) Perusahaan pertambangan yang menggunakan mata uang rupiah sebagai mata uang pelaporan. 4) Perusahaan pertambangan yang selama tahun pengamatan yakni, 2015-2017 mempunyai biaya-biya produksi dan luas area pabrik. 5) Perusahaan tidak dikeluarkan dari bursa (delisted) pada periode sampel.

\section{Tekhnik Pengumpulan Data}


Metode pengumpulan data pada penelitian ini adalah dengan metode dokumentasi, yakni penggunaan data yang berasal dari dokumen-dokumen yang sudah ada. Hal ini dilakukan dengan cara melakukan penelusuran data-data yang diperlukan dari laporan publikasi perusahaan tahun 20152017. Data ini diperoleh dari website Indonesian Stock Exchange (IDX) dan Indonesian Capital Market Directory (ICMD).

\section{Biaya Produksi}

Biaya produksi adalah biaya yang terjadi pada fungsi produksi. Fungsi produksi adalah fungsi mengolah bahan baku menjadi barang jadi (Riwayadi 2014:47). Biaya merupakan salah satu sumber informasi yang paling penting dalam analisis strategi perusahaan. Pada dasarnya masalah yang sering timbul dalam suatu perusahaan adalah perencanaan biaya oleh suatu perusahaan.

\section{Luas Area Pabrik Produksi}

Luas area pabrik produksi sangat penting dalam menunjang kegiatan produksi. Di dalam dunia industri, masalah tata letak pabrik maupun tata letak fasilitas dan peralatan produksi merupakan salah satu faktor yang berperan penting dalam peningkatan produktivitas perusahaan. Semakin besar luas lahan maka semakin besar produktivitas yang di hasilkan (Ambarita dan Kartika 2015).

Lahan adalah salah satu faktor produksi, tempat dihasilkannya produk yang memiliki peran penting terhadap suatu perusahaan, karena banyak sedikitnya hasil produksi sangat dipengaruhi oleh luas sempitnya lahan yang digunakan.

\section{Hasil atau Nilai Produksi}

Sudarsono dalam Ningsih dan Indrajaya (2015), nilai produksi merupakan seluruh tingkat suatu produksi yang berdasarkan atas harga jual produk-produk tersebut menggunakan faktor-faktor produksi yang dimiliki oleh perusahaan dalam satu periode yang pada akhirnya akan dijual kepada pembeli.

\section{Tekhnik Pengujian Hipotesis}

Tekhnik analisis yang digunakan untuk menguji hipotesis penelitian ini adalah analisis regresi linier berganda dan analisis regresi moderasi dengan pendekatan nilai selisih mutlak dengan persamaan sebagai berikut:

$$
\begin{aligned}
& Y=a+\beta_{1} X_{1}+\beta_{2} X_{2}+\beta_{3} X_{3}+\beta_{3} Z+\beta_{4}\left[X_{1-}\right. \\
& \mathrm{Z}]+\beta_{5}\left[\mathrm{X}_{2}-\mathrm{Z}\right]+\beta_{6}\left[\mathrm{X}_{3}-\mathrm{Z}\right]+\mathrm{e} \\
& \text { Keterangan: } \\
& \mathrm{Y}=\text { Keberlangsungan Perusahaan } \\
& \mathrm{a}=\text { Konstanta } \\
& \mathrm{X}_{1} \quad=\text { Biaya Produksi } \\
& \mathrm{X}_{2} \quad=\text { Luas area pabrik } \\
& \mathrm{X}_{3} \quad=\text { Hasil atau Nilai Produksi } \\
& \mathrm{Z}=\text { Green Accounting } \\
& {[\mathrm{X} 1-\mathrm{Z}]=\text { MFCA (Biaya produksi) ber }}
\end{aligned}
$$

Hipotesis diuji dengan menggunakan tingkat signifikansi $(\alpha)=0,05$ atau $5 \%$. Untuk menguji pengaruh material flow cost accounting dalam meningkatkan keberlangsungan perusahaan, biaya produksi, luas area pabrik, hasil atau nilai produksi terhadap keberlangsungan perusahaan dilakukan dengan menguji nilai $t$ pada tingkat signifikansi $(\alpha)=0,05$. Demikian halnya, pengujian hipotesis yang menunjukkan interaksi green accountting dalam meningkatkan pengaruh MFCA (biaya produksi, luas area pabrik dan hasil atau nilai produksi) terhadap keberlangsungan perusahaan. 


\section{ANALISIS DAN PEMBAHASAN \\ Deskriptif Variabel}

Deskriptif variabel penelitian berdasarkan perolehan data 36 dari 4 perusahaan dengan perhitungan triwulan ditunjukkan pada Tabel 1. Tebel 1 menunjukkan bahwa nilai rata-rata tertinggi berada pada variabel green accounting sebesar 70,8333, selanjutnya keberlangsungan perusahaan sebesar 26,
7011, biaya produksi sebesar 25,1235. Hasil atau nilai produksi sebesar 24,3398 , luas area produksi sebesar 8,5129. Variabel green accounting, keberlangsungan perusahaan dan biaya produksi menunjukkan nilai ratarata sebesar 70,8333, 26,7011 dan 25,1235 yang lebih mendekati angka maksimumnya masing-masing, dibandingkan variabel luas area produksi dan hasil atau nilai produksi.

Tabel 1

Uji statistik Deskriptif Variabel

Deskriptive Statistics

\begin{tabular}{lccccc}
\hline & N & Minimum & Maximum & Mean & Std.Deviation \\
\hline Biaya produksi & 36 & 21,57 & 29,29 & 25,1235 & 2,24729 \\
Luas area produksi & 36 & 3,80 & 13,14 & 8,5129 & 3,40099 \\
Hasil atau nilai produksi & 36 & 19,65 & 27,51 & 8,5129 & 1,72450 \\
Green Accounting & 36 & 60,00 & 90,00 & 70,8333 & 9,67323 \\
Keberlangsungan & 36 & 24,29 & 29,57 & 26,7011 & 1,56535 \\
Perusahaan Valid N (listwise) & 36 & & & & \\
\hline
\end{tabular}

Sumber: Olah Data SPSS 222018

Perusahaan pertambangan memiliki green accounting yang tinggi terhadap perusahaannya dan juga keberlangsungan perusahaan yang tinggi, serta biaya produksi. Standar deviasi tertinggi berada pada variabel green accounting sebesar 9,67323, selanjutnya luas area pabrik produksi sebesar 3,40099 , biaya produksi sebesar 2,24729 , hasil atau nilai produksi sebesar 1,72450.

\section{Uji Asumsi Klasik}

Uji Normalitas

Hasil uji normalitas dengan menggunakan uji Kolmogorov-Smirnov (K-S) pada Tabel 2 menunjukkan nilai 0,801 dengan tingkat signifikansi sebesar 0,543. Karena hasil Kolmogorov-Smirnov menunjukkan signifikansi diatas 0,05 maka hal tersebut menunjukkan bahwa data residual terdistribusi secara normal.

Tabel 2

Hasil Uji Kolmogorof-Smirnov (K-S)

One-Sample Kolmogorov-Smirnov Test

\begin{tabular}{llr}
\hline \hline & & Unstandardized Residual \\
\hline $\mathrm{N}$ & & 36 \\
Normal Parametersa,b & Mean &, 0000000 \\
& Std. Deviation &, 70038420 \\
& Absolute &, 133 \\
Most Extreme Differences & Positive &, 070 \\
& Negative &,- 133 \\
Kolmogorov-Smirnov Z & &, 801 \\
Asymp. Sig. (2-tailed) & &, 543 \\
\hline
\end{tabular}

a. Test distribution is Normal.

b. Calculated from data.

Sumber: Olah Data SPSS 222018 
Hasil uji ini memperkuat hasil uji normalitas dengan grafik distribusi dimana keduanya menunjukkan hasil bahwa data terdistribusi secara normal. Hasil uji normalitas pada gambar dibawah dengan menggunakan normal probability plot yang membandingkan distribusi kumulatif dari distribusi normal. Normalitas dapat dideteksi dengan melihat penyebaran data (titik) pada sumbu diagonal dari grafik. Jika data (titik) menyebar disekitar garis diagonal dan mengikuti arah garis diagonal maka menunjukkan pola distribusi normal yang mengindikasikan bahwa regresi memenuhi asumsi normal. Hasil yang ditunjukkan pada gambar dibawah ini, dimana terlihat pada gambar tersebut bahwa titik-titik menyebar di sekitar garis diagonal serta penyebarannya mengikuti garis diagonal sehingga dapat disimpulkan bahwa data dalam model regresi dengan uji normalitas terdistribusi secara normal.

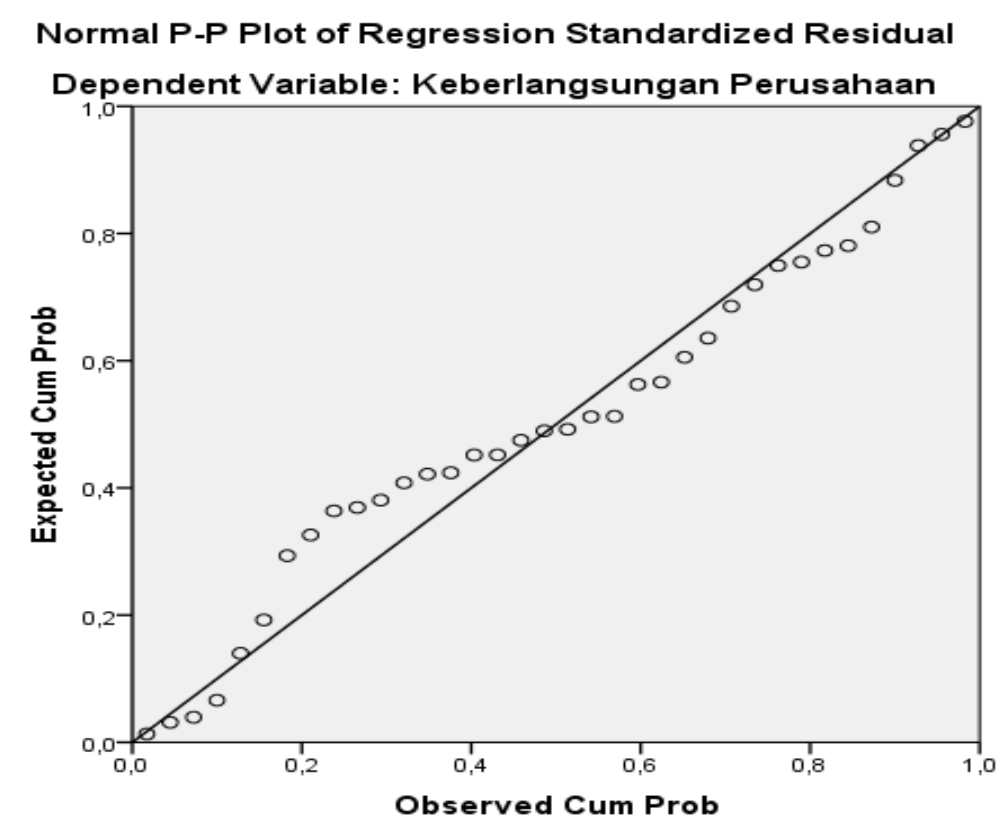

Sumber: Data diolah, 2018

Gambar 1

Grafik P-P Plot

\section{Uji Multikolinearitas}

Uji multikolonieritas dilakukan untuk menguji apakah pada model regresi ditemukan korelasi antar variabel independen. Jika tidak terjadi korelasi antar variabel independen maka dapat dikatakan bahwa model regresi tersebut baik. Untuk mengetahui adanya multikolinieritas, dapat dilihat dari nilai Tolerance dan Variance Inflation Factor (VIF). Nilai cut-off yang biasa dipakai untuk menunjukkan adanya multikolonieritas adalah nilai tolerance $<0,10$ atau sama dengan nilai VIF.

Hasil uji multikolonieritas tabel 4 dibawah dilihat bahwa nilai tolerance biaya produksi 0,147 luas area pabrik 0,335 dan hasil atau nlai produksi 0,382, dan green accounting 0,324. Ketiga variabel independen dan variabel moderasi dalam penelitian ini memiliki nilai tolerance diatas 0,10 yang berarti bahwa tidak terjadi korelasi antar variabel independen. Hasil yang sama dilihat dari nilai VIF ketiga variabel independen dan variabel moderasi yang menunjukkan angka dibawah 10 (biaya produksi 6,802, Luas Area Pabrik 2,984, Hasil atau Nilai Produksi 2,617 dan Green Accounting 3,087). Jadi dapat disimpulkan bahwa model regresi terbebas dari multikolinieritas antar variabel. 
Tabel 3

Hasil Uji Multikolonieritas

Coefficients

\begin{tabular}{|c|c|c|c|c|c|c|c|}
\hline \multirow{2}{*}{ Model } & \multicolumn{2}{|c|}{$\begin{array}{l}\text { Unstandardized } \\
\text { Coefficients }\end{array}$} & $\begin{array}{l}\text { Standardized } \\
\text { Coefficients }\end{array}$ & \multirow{2}{*}{$\mathbf{T}$} & \multirow{2}{*}{ Sig. } & \multicolumn{2}{|l|}{$\begin{array}{l}\text { Collinearity } \\
\text { Statistics }\end{array}$} \\
\hline & B & $\begin{array}{l}\text { Std. } \\
\text { Error }\end{array}$ & Beta & & & Tolerance & VIF \\
\hline (Constant) & 4,375 & 1,114 & & 3,926 & ,000 & & \\
\hline Biaya Produksi &,- 119 & ,084 &,- 564 & $-1,424$ & 164 & 147 & 6,802 \\
\hline Luas Area Pabrik & ,022 & ,037 & ,157 & ,600 &, 533 & ,335 & 6,802 \\
\hline $\begin{array}{l}\text { Hasil atau Nilai } \\
\text { Produksi }\end{array}$ & 104 & ,068 &,- 376 & $-1,529$ & 136 & ,382 & 2,617 \\
\hline Green Accounting & ,021 & ,013 & ,422 & 1,580 & 124 & ,324 & 3,087 \\
\hline
\end{tabular}

a. Dependent: Keberlangsungan

Perusahaan

Sumber: Olah Data SPSS 222018

\section{Uji Heteroskedastisitas}

Grafik scatterplot dibawah ini terlihat bahwa sebaran titik-titik menyebar secara acak dan tersebar baik diatas maupun dibawah 0 pada sumbu Y. Hal ini dapat disimpulkan bahwa tidak terjadi heteroskedastisitas pada model regresi, sehingga model regresi layak digunakan pada penelitian ini.

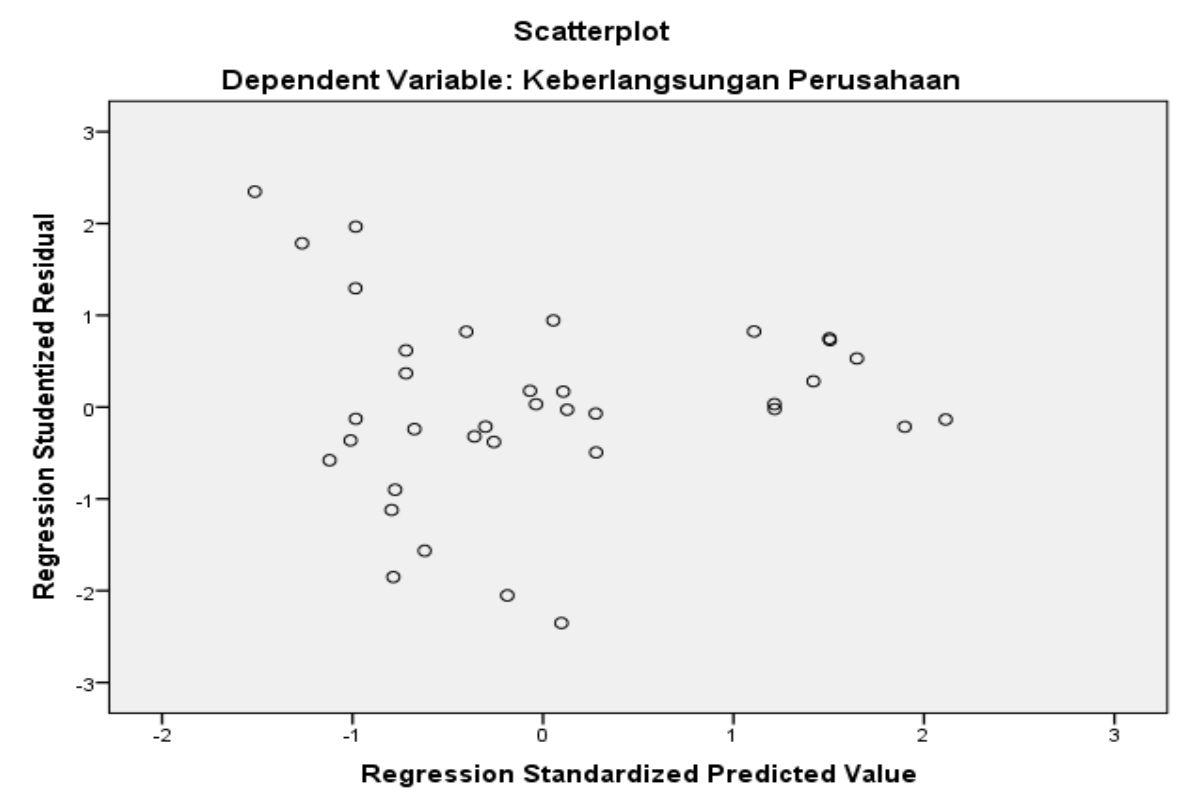

Sumber: Data diolah, 2018

Gambar 2

Grafik Scatterplot

\section{Uji autokorelasi}

Hasil uji autokorelasi pada Tabel 4 dibawah dapat dilihat bahwa nilai Durbin Watson adalah 1,950. Dengan signifikansi
$5 \%$, jumlah unit analisis 36 (n) dan variabel independen $3(\mathrm{k}=3)$, didapat nilai $\mathrm{dl}=1,2953$ dan $d u=1,6539$. Nilai DW adalah 1,950 dan berada di antara du dan 4-du. Artinya 1,950 
lebih dari du $(1,6539)$ maka dapat disimpulkan bahwa tidak terdapat masalah auto- korelasi pada model, sehingga model regresi layak dipakai untuk analisis selanjutnya.

Tabel 4

Hasil Uji Autokorelasi

\begin{tabular}{cccccc}
\hline \hline Model & $\mathbf{R}$ & R Square & $\begin{array}{c}\text { Adjusted } \mathbf{R} \\
\text { Square }\end{array}$ & $\begin{array}{c}\text { Std. Error of the } \\
\text { Estimate }\end{array}$ & Durbin-Watson \\
\hline 1 &, 894 &, 800 &, 774 &, 774420 & 1,950 \\
\hline
\end{tabular}

a. Predictors: (Constant), Green Accounting, Luas Area Pabrik, Hasil/Nilai Produksi, Biaya Produksi.

b. Dependent Variable: Keberlangsungan Perusahaan

\begin{tabular}{|c|c|c|c|}
\hline Model & R Square & Std. Error of the Estimate & Durbin-Watson \\
\hline 1 & ,894 800 & ,774420 & 1,950 \\
\hline
\end{tabular}

\section{Hasil Pengujian Hipotesis Koefisien Determinasi}

Tabel 5 berikut ini menunjukkan bahwa nilai $\mathrm{R}^{2}$ 0,797. Hal ini berarti 79,7\% variabel dependen (Keberlangsungan perusahaan) dapat dijelaskan oleh ketiga variabel independen yaitu biaya produksi, luas area pabrik dan hasil atau nilai produksi dan variabel moderasi (green accounting), sedangkan sisanya 20,3\% dipengaruhi oleh variabel lain yang tidak diteliti dalam penelitian ini.

\section{Uji Regresi Secara Simultan (f)}

Berdasarkan hasil uji anova atau uji $\mathrm{F}$ pada Tabel 6 menunjukkan bahwa nilai $\mathrm{F}$ sebesar 41,926 dan nilai signifikansi sebesar 0,000 . Dengan demikian model penelitian ini layak digunakan, sehingga pengujian secara parsial dapat dilanjutkan.

\section{Uji Regresi Linear Berganda}

Penelitian ini konsisten menggunakan signifikan level 0,05 ( $\alpha=5 \%)$. Dengan demikian nilai statistik pada Tabel 7 menunjukkan bahwa luas area pabrik produksi tidak berpengaruh signifikan terhadap keberlangsungan perusahaan. Disisi lain, tingkat biaya produksi dan hasil atau nilai produksi berpengaruh signifikan terhadap keber- langsungan perusahaan. Hasil pengujian pada Tabel 7, nilai kolom B baris pertama menunjukkan konstanta (a) dan baris selanjutnya menunjukkan konstanta variabel independen. Hasil pengujian hipotesis secara statistik menunjukkan bahwa koefisien regresi variabel biaya produksi 0,393 dengan tingkat signifikansi sebesar 0,003 yang lebih kecil dari 0,05 maka $\mathrm{H}_{1}$ diterima. Ini berarti biaya produksi berpengaruh positif dan signifikan terhadap keberlangsungan perusahaan. Hal tersebut kemungkinan disebabkan karena semakin banyak biaya produksi yang dikeluarkan perusahaan nantinya akan menyebabkan MFCA (biaya produksi) akan berpengaruh terhadap keberlangsungan perusahaan. Temuan ini konsisten dengan hasil penelitian Kourilova dan Plevkova (2013) tentang model deteksi MFCA dengan akuntansi lingkungan menunjukkan bahwa MFCA dapat digunakan sebagai model untuk mendeteksi produksi dan bisnis sebuah perusahan.

Penelitian Fakoya (2014) terdapat pengaruh penggunaan tekhnologi dan material flow cost accounting dalam mendukung proses pengambilan keputusan manajemen perusahaan untuk pengurangan limbah. 
Tabel 5

Hasil uji koefisien determinasi

\begin{tabular}{cclrrc}
\hline Model & R & R Square & Adjusted & R Square & Std. Error of the Estimate \\
\hline 1 &, $893^{\mathrm{a}}$ &, 797 &, 778 &, 73727 \\
\hline
\end{tabular}

a. Predictors: (Constant), hasil/nilai produksi, luas area pabrik, biaya produksi

Sumber: Olah Data SPSS 222018

Tabel 6

Hasil Uji Statistik F

ANOVA

\begin{tabular}{llrrrrr}
\hline \hline & Model & Sum of Square & Df & Mean Square & \multicolumn{1}{c}{ F } & Sig. \\
\hline \multirow{2}{*}{1} & Regression & 68,368 & 3 & 22,789 & 41,926 &, $000^{\mathrm{b}}$ \\
& Residual & 17,394 & 32 &, 544 & & \\
& Total & 85,762 & 32 & & & \\
\hline
\end{tabular}

a. Dependent Variabel: Keberlangsungan Perusahaan

b. Predictors: (Constant), Hasil/Nilai Produksi, Luas Area Produksi, Biaya Produksi Sumber: Olah Data SPSS 222018

Tabel 7

Hasil Uji Regresi Linear

Coefficients $^{\mathrm{a}}$

\begin{tabular}{|c|c|c|c|c|c|}
\hline \multirow[t]{2}{*}{ Model } & \multicolumn{2}{|c|}{$\begin{array}{l}\text { Unstandardized } \\
\text { Coefficients }\end{array}$} & $\begin{array}{l}\text { Standardized } \\
\text { Coefficients }\end{array}$ & \multirow[t]{2}{*}{$\mathbf{t}$} & \multirow[t]{2}{*}{ Sig. } \\
\hline & B & Std. Error & Beta & & \\
\hline (Constant) & 8,843 & 1,821 & & 4,857 & ,000 \\
\hline Biaya Produksi & ,393 & ,122 &, 564 & 3,207 & ,003 \\
\hline Luas Area Pabrik & ,059 & ,063 & 128 & 9,35 & ,357 \\
\hline Hasil/Nilai Produksi & ,308 & ,116 & ,339 & 2,649 & ,012 \\
\hline
\end{tabular}

a. Dependent Variable: Keberlangsungan Perusahaan

Sumber: Olah Data SPSS 222018

Variabel luas area pabrik mempunyai koefisien regresi sebesar 0,59 dan tingkat signifikansi 0,357 maka $\mathrm{H}_{2}$ ditolak. Dengan demikian luas area produksi tidak berpengaruh dan tidak signifikan terhadap keberlangsungan perusahaan. Hal ini disebabkan adanya setiap peningkatan luas area pabrik produksi tidak menjamin meningkatkan keberlangsungan suatu perusahaan. Artinya, semakin luas area pabrik perusahaan yang dimiliki maka tidak meningkatkan keberlangsungan dalam perusahaan. Luasnya lahan dapat mengakibatkan upaya melakukan tindakan yang mengarah pada segi efisiensi akan berkurang disebabkan lemahnya faktor produksi ataupun tidak efisiensi biaya-biaya produksi yang dikeluarkan perusahaan, terbatasnya persediaan tenaga kerja ataupun faktor lingkungan perusahaan. Penelitian Ambarita dan Kartika (2015) menunjukkan bahwa semakin besar luas lahan maka semakin besar produktivitas yang di hasilkan. Tata letak pabrik adalah suatu landasan utama dalam dunia industri. Plant layout atau facilities layout didefinisikan sebagai tata cara pengaturan fasilitasfasilitas pabrik guna menunjang kelancaran proses produksi, jarak material handling dalam area produksi akan mempengaruhi lintasan dan waktu proses dari produksi (Pratiwi, et al., 2012).

Variabel hasil atau nilai produksi mempunyai koefisien regresi sebesar 0,308 
dan tingkat signifikansi 0,012 yang lebih kecil dari 0,05, maka $\mathrm{H}_{3}$ diterima. Hal ini berarti hasil atau nilai produksi berpengaruh positif dan signifikan terhadap keberlangsungan perusahaan. Hasil pengujian ini konsisten dengan penelitian Sudarsono dalam Ningsih dan Indrajaya (2015), nilai produksi merupakan seluruh tingkat suatu produksi yang berdasarkan atas harga jual produk-produk tersebut menggunakan faktor-faktor produksi yang dimiliki oleh perusahaan dalam satu periode yang pada akhirnya akan dijual kepada pembeli. Hasil produksi mengalami peningkatan, jika produsen mempunyai kecenderungan meningkatkan kapasitas produksinya. Hal tersebut akan menyebabkan kapasitas produksinya juga akan ditambah. Untuk meningkatkan output, diperlukan peningkatan input yang dalam hal ini tenaga kerja. Semakin tinggi produktivitas tenaga kerja semakin tinggi pula jumlah produksi, begitu juga sebaliknya (Sumarsono, 2003 dalam
Fadliilah dan Atmanti, 2012). Hasil penelitian ini didukung dengan hasil penelitian Marota (2017) yang menunjukkan bahwa MFCA dengan hasil atau nilai produksi berpengaruh signifikan terhadap keberlangsungan suatu perusahaan.

Hasil penelitian Putra (2012) mengungkapkan bahwa nilai produksi memiliki pengaruh yang signifikan terhadap suatu perusahaan.

\section{Hasil uji regresi moderasi nilai selisih mutlak}

Hasil uji statistik pada Tabel 8 dibawah ini, menunjukkan bahwa variabel green accounting hanya mampu memoderasi material flow cost accounting (hasil atau nilai produksi) terhadap keberlangsungan perusahaan. Hal ini tersebut tampak bahwa X3_M dengan tingkat signifikansi 0,044 < 0,05 . Hal ini berarti bahwa variabel green accounting tidak mampu memoderasi variabel lainnya.

Tabel 8

Hasil Uji Selisih Mutlak Coefficients ${ }^{a}$

\begin{tabular}{|c|c|c|c|c|c|}
\hline \multirow[t]{2}{*}{ Model } & \multicolumn{2}{|c|}{$\begin{array}{l}\text { Unstandardized } \\
\text { Coefficients }\end{array}$} & $\begin{array}{l}\text { Standardized } \\
\text { Coefficients }\end{array}$ & \multirow[t]{2}{*}{$\mathbf{t}$} & \multirow[t]{2}{*}{ Sig. } \\
\hline & B & Std. Error & Beta & & \\
\hline (Constant) & 62,082 & 23,907 & & 2,579 & 015 \\
\hline Biaya Produksi & ,461 & 1,390 & ,662 & ,332 & 743 \\
\hline Luas Area Pabrik &,- 652 & 1,361 & $-1,416$ &,- 479 & 636 \\
\hline Hasil/Nilai Produksi & $-1,689$ & ,948 & $-1,861$ & $-1,781$ & , 086 \\
\hline Green Accounting &,- 753 & 343 & $-4,652$ & $-2,192$ & ,037 \\
\hline X1_M &,- 001 & ,020 &,- 273 &,- 054 & ,957 \\
\hline X2_M & ,009 & ,019 & 1,765 & 456 & 652 \\
\hline X3_M & ,029 & ,014 & 5,879 & 2,104 & ,044 \\
\hline
\end{tabular}

a. Dependent Variable: Keberlangsungan Perusahaan

Sumber: Olah Data SPSS 222018

Hasil uji nilai selisih mutlak yang terlihat pada Tabel 8 menunjukkan bahwa variabel moderating $\mathrm{X} 1 \_\mathrm{M}$ tidak signifikan dengan nilai koefisien regresi (standardized coefficients) sebesar $-0,001$ dan angka signifikansi sebesar 0,957 (lebih besar dari $0,05)$. Variabel green accounting tidak memoderasi biaya produksi terhadap ke- berlangsungan perussahaan $\left(\mathrm{H}_{3}\right.$ ditolak). Justifikasi atas tidak adanya interaksi atau moderasi green accounting tidak memoderasi biaya produksi terhadap keberlangsungan perusahaan adalah bahwa bahwa green accounting dalam perusahaan tersebut tidak memiliki dampak signifikan dalam meningkatkan pengaruh MFCA (biaya pro- 
duksi) terhadap keberlangsungan perusahaan. Sejalan dengan pernyataan Kusumaningtyas (2013) yang mengungkapkan bahwa laporan keuangan belum mampu menghadirkan informasi pelaporan aktivitas pemberdayaan lingkungan (green accounting). Berarti bahwa tidak selamanya green accounting akan memberikan pengaruh signifikan bagi perusahaan karena masih banyak perusahaan-perusahaan yang memasukkan biaya-biaya lingkungan atau green accounting kedalam biaya-biaya lain sehingga manajer sulit untuk mengetahuinya.

Variabel moderating X2_M signifikansi dengan nilai koefisien regresi (standardized coefficients) sebesar 0,009 dan angka signifikansi sebesar 0,652 (lebih besar dari 0,05). Hal ini berarti variabel green accounting tidak memoderasi luas area produksi terhadap keberlangsungan perussahaan $\left(\mathrm{H}_{4}\right.$ ditolak). Hasil uji ini memiliki arti bahwa green accounting dalam perusahaan tersebut tidak memiliki dampak signifikan dalam meningkatkan pengaruh MFCA (luas area pabrik produksi) terhadap keberlangsungan perusahaan.

Variabel moderating X3_M signifikansi dengan nilai koefisien regresi (standardized coefficients) sebesar 0,29 dan angka signifikansi sebesar 0,044. Hal ini berarti bahwa variabel green accounting memoderasi hasil atau nilai produksi terhadap keberlangsungan perussahaan $\left(\mathrm{H}_{5}\right.$ diterima). Hasil penelitian ini didukung dengan hasil penelitian Marota (2017) menunjukkan bahwa MFCA dengan variabel nilai produksi berpengaruh signifikan terhadap keberlangsungan suatu perusahaan. Sejalan dengan penelitian Burhany (2014) menunjukkan bahwa akuntansi lingkungan berpengaruh positif dan signifikan terhadap kinerja lingkungan, dan akuntansi lingkungan dan kinerja lingkungan berpengaruh positif dan signifikan terhadap pengungkapan informasi lingkungan, baik secara simultan maupun parsial. Penelitian yang dilakukan Loen (2018) membuktikan bahwa material flow cost accounting dan green accounting dapat meningkatkan keberlangsungan suatu perusahaan. Green accounting yang terstruktur akan memberikan kontribusi baik pada perusahaan. Hasil ini menimbulkan implikasi terhadap perlunya praktik akuntansi perusahaan diperluas dengan memasukkan aspek lingkungan. Dengan demikian, akuntansi dapat berkontribusi dalam pertanggungjawaban lingkungan perusahaan.

\section{SIMPULAN DAN SARAN}

Biaya produksi memiliki pengaruh positif terhadap keberlangsungan perusahaan. Perusahaan yang mengeluarkan biaya produksi memiliki target atau tujuan untuk dicapai, salah satu tujuan tersebut adalah untuk mendapatkan hasil yang diinginkan dengan meminimalkan pengeluaran biayabiaya yang terjadi dalam proses produksi serta dapat meningkatkan keberlangsungan perusahaan. Komponen Luas area pabrik produksi tidak berpengaruh dalam meningkatkan keberlangsungan perusahaan. Perusahaan yang memiliki luas area pabrik tidak menjamin untuk meningkatkan keberlangsungan suatu perusahaan apabila tata letak pabrik atau tata cara pengaturan fasilitas-fasilitas pabrik tidak sesuai atau tidak strategis bagi perusahaan. Hasil atau nilai produksi berpengaruh positif dalam meningkatkan keberlangsungan perusahaan. Perusahaan dengan MFCA (hasil produksi) dapat meningkatkan keberlangsungan perusahaan. MFCA dapat meningkatkan laba dan produktivitas (internal) serta mengurangi dampak negatif lingkungan (eksternal) yang selanjutnya dapat berkontribusi dalam pengembangan keberlanjutan perusahaan. Green accounting tidak memoderasi dalam meningkatkan pengaruh MFCA (biaya produksi) terhadap keberlangsungan perusahaan. Tidak selamanya green accounting akan memberikan pengaruh signifikan bagi perusahaan karena masih banyak perusahaan-perusahaan yang memasukkan biaya-biaya lingkungan atau green accounting kedalam biaya-biaya lain. Green accounting tidak memoderasi dampak dalam meningkatkan komponen luas area 
pabrik produksi terhadap keberlangsungan perusahaan. Pengungkapan green accounting dalam suatu perusahaan hanya dilandaskan faktor suka rela sehingga banyak perusahaan tidak mengungkapkan aktivitasaktivitas yang dilakukanya dalam pelestarian lingkungan. Green accounting memoderasi dampak dalam meningkatkan pengaruh bentuk komponen hasil atau nilai produksi terhadap keberlangsungan perusahaan. Hasil uji membuktikan bahwa green accounting dalam perusahaan tersebut memiliki dampak signifikan dalam meningkatkan pengaruh hasil atau nilai produksi terhadap keberlangsungan perusahaan. Perusahaan dengan green accounting yang baik akan memberikan kepercayaan masyarakat sehingga perusahaan dapat beroperasi terus menerus.

Penelitian ini diharapkan menjadi acuan bagi perusahaan pertambangan yang ada dibursa efek Indonesia untuk meningkatkan pelestarian lingkungan. Material Flow Cost Acconting MFCA bermanfaat bagi perusahaan untuk peningkatan keberlanjutan perusahaan khususnya dalam mengurangi masalah dampak limbah, penggunaan material dan energi yang tidak efisien dan mengurangi biaya keuangan perusahaan. Memberikan kontribusi pengetahuan ilmu akuntansi yang khususnya membahas efek green accounting terhadap matarial flow cost accounting dalam meningkatkan keberlangsungan perusahaan. Bagi manajemen agar dapat memisahkan biaya limbah untuk produk utama dan produk sampingan dengan menggunakan metode material flow cost accounting. Bagi penelitian selanjutnya diharapkan dapat mengamati variabel lainnya dan lebih mengembangkan penelitian tentang MFCA karena masih kurang dalam dunia penelitian terkait MFCA dengan variabel-variabel lainnya

\section{DAFTAR PUSTAKA}

Agustia, D. 2010. Pelaporan biaya lingkungan Sebagai Alat Bantu Bagi Pengambilan Keputusan yang Berkaitan dengan Pengelolaan Lingkungan. Jurnal Akuntansi: Akrual 1(2): 80-100.

Ahmad, N. N. N. dan D. M. Hossain. 2015. Climate Change and Global Warming Discourses and Disclosures in the Corporate Annual Reports: A Study on the Malaysian Companies. Procedia Social and Behavioral Sciences 172: 246253.

Alfian, R., R. Hamzah, dan H. A. Dede. 2020. Analisa Implementasi Material Flow Cost Accounting (MFCA) pada Perusahaan Industri (Studi Kasus pada PT. Unipres Indonesia). E-Jurnal Apresiasi Ekonomi 8(1): 86-98.

Ambarita, J. P. dan I N. Kartika. 2015. Pengaruh Luas Lahan, Pnggunaan Pestisida, Tenaga Kerja, Pupuk Terhadap Produksi Kopi Di Kecamatan Pekutatan Kabupaten Jembrana. EJurnal Ekonomi Pembangunan Universitan Udayana 4(7): 746-872.

Amiruddin. 2012. Etika Lingkungan Dalam Pengelolaan Lingkungan Hidup. Jurnal Nominal 3(1): 137-147.

Aminah dan Noviani. 2014. Analisis Penerapan Akuntansi Lingkungan di Rumah Sakit Mardi Waluyo Metro. Jurnal Akuntansi dan Keuangan 5(2): 1-16.

Aniela, Y. 2012. Peran Akuntansi Lingkungan Dalam Meningkatkan Kinerja Lingkungan Dan Kinerja Keuangan Perusahaan. Berkala Ilmiah Mahasiswa Akuntansi 1(1).

Astuti, N. 2012. Mengenal Green Accounting. PERMANA 5(1): 69-75.

Bare, J. C. 2011. Five Key Elements for Enviromental Sustainable Progress. International Journal for Sustainable Innovations 1(1): 91-98.

Burhany, D. I. 2014. Pengaruh Implementasi Akuntansi Lingkungan terhadap Kinerja Lingkungan dan Pengungkapan Informasi Lingkungan (Studi pada Perusahaan Pertambangan Umum yang Mengikuti PROPER Periode 2008-2009). Indonesian Journal of Economics and Business, 1(2): 257-270. 
Cohen, J. R., L. H. Nath, dan D. Wood. 2009. The Supply of Corporate Social Responsibility Disclosures among U.S. Firms. Journal of Business Ethics, 84(4): 497-527.

Danny, A. dan N. Marhaeni. 2017. Analisis Skala Ekonomi Dan Efisiensi Pengunaan Faktor-Faktor Produksi Pada Usaha Perkebunan Kopi Arabika Di Desa Satra Kecamatan Kintamani Kabupaten Bangli. EJurnal Ekonomi Pembangunan Universitan Udayana 6(2): 178-194.

Descalu, C., C. Caraiani, C. I. Lungu, F. Colceag, dan G. R. Guse. 2010. The Externalities in Social Environmental Accounting. International Journal of Accounting and Information Management 18(1): 19-30.

Fadliilah, D. N. dan H. D. Atmanti. 2012. Analisis Penyerapan Tenaga Kerja pada Industri Kecil (Studi Kasus di Sentra Industri Kecil Ikan Asin di Kota Tegal. Diponegoro Journal of Economics 1(1): 1-13.

Fakoya, M. B. 2014. An Adjusted Material Flow Cost Accounting Framework for Proces Waste-reduction Decisions in the South African Brewery Industry. Disertasi. University of South Africa. Pretoria.

Farouk, S., J. Cherian, dan J. Jacob. 2012. Green Accounting and Management for Sustainability Manufacturing in Developing Countries. International Journal of Business and Management 7(20): 36-43.

Ghomi, B. Z. dan P. Leung. 2013. An Empirical Analysis of the Determinants of Greenhouse Gas Voluntary Disclosure in Australia. Accounting and Finance Research 2(1): 110-127.

Hernadi, B. H. 2012. Green Accounting for Corporate Sustainibility. Club of Economics di Miskolc' TMP 8(2): 23-30.

Hyrslova, J., M. Vagner, dan J. Palasek. 2011. Material Flow Cost Accounting (MFCA)-Tool for the Optimization of Corporate Production Processes. Business, Management and Education Journal 9(1): 5-18.
Idris. 2012. Akuntansi Lingkungan sebagai Instrumen Pengungkapan Tanggung Jawab Perusahaan terhadap Lingkungan di Era Green Market. Jurnal economic 2(2): 1-10.

Jasch, Ch. 2009. Environmental and Material Flow Cost Accounting. Principles and Procedures. Springer. United Kingdom.

Kourilova, J. dan D. Plevkova. 2013. DMFCA Model as a Possible Way to Detect Accounting and Accounting Fraud in an Enterprise. Financial Asset and Investing Journal 2(2): 14-27.

Kusumaningtias, R. 2013. Green Accounting, Mengapa dan Bagaimana?. Jurnal Akuntansi dan Keuangan 7(2): 137-149.

Laan, S. 2009. The Role of Theory in Explaining Motivation for Corporate Social Disclosures: Voluntary Disclosures vs Solicited Disclosures. Australasian Accounting Business and Finance Journal 3(4).

Lynch, K. D. 2011. Measuring Corporate Sustainability Performance: Influences and Issues to Consider in Metric Conceptualization. Disertation. Benedictine University. Illinois.

Lindawati, A. S. dan M. E. Puspita. 2015. Corporate Social Responsibility: Implikasi Stakeholder dan Legitimacy Gap dalam Meningkatkan Kinerja Perusahaan. Jurnal Akuntansi Multiparadigma 6(1): 157-174.

Loen, M. 2018. Penerapan Green Accounting dan Material Flow Cost Accounting (MFCA) terhaadap Sustainable Development. Jurnal Akuntansi dan Bisnis Krisnadwipayana 5(1): 1-13.

Luo, L., Q. Tang, dan Y. Lan. 2013. Comparison of Propensity for Carbon Disclosure between Developing and Developend Countries: A Resource Constraint Perspektif. Accounting Research Journal 1(2): 6-34.

Mahmoudi, E., N. Jodeiri, dan E. Fatehifar. 2017. Implementation of Material Flow Cost Accounting for Efficiency Improvement in Wastewater Treatment Unit of Tabriz Oil Refining Company. Journal of 
Cleaner Production, 165 (Supplement C): 530-536.

Marota, R., M. Marimin, dan H. Sasongko. 2015. Perancangan dan Penerapan MFCA untuk Peningkatan Keberlanjutan Perusahaan PT XYZ. Jurnal Manajemen dan Agribisnis 12(2): 92-105.

Marota, R. 2017. Green Concepts and Material Flow Cost Accounting Application for Company Sustainability. Indonesian Journal of Business and Entrepreneurship 3(1): 43-51.

Maulida, K. A. dan H. Adam. 2012. FaktorFaktor Yang Mempengaruhi Pengungkapan Sustainability Performance. Jurnal Ilmiah Mahasiswa FEB.

Nakajima, M., A. Kimura, dan B. Wagner. 2014. Introduction of MFCA to the Supply Chain: a Questionnaire Study on the Challenges of Constructing a LowCarbon Supply Chain to Promote Resource Efficiency. Journal of Cleaner Production 108(B): 1302-1309.

Ningsih, N. M. C. dan I. G. Indrajaya. 2015. Pengaruh Modal dan Tingkat Upah terhadap Nilai Produksi serta Penyerapan Tenaga Kerja pada Industri Kerajinan Perak. Jurnal Ekonomi Kuantitatif Terapan 8(1): 83-91.

Rahmayanti, Dian Rhesa. 2014. Implementasi Corporate Social Responsibility dalam Membangun Reputasi Perusahaan. Jurnal ILMU KOMUNIKASI 11(1): 93-104.

Rakhiemah, A. N. dan A. Dian. 2009. Pengaruh Kinerja Lingkungan Terhadap Corporate Social Responsibility (CSR) dan Kinerja Finansial Perusahaan Manufaktur yang Terdaftar di Bursa Efek Indonesia. Jurnal dan Prosiding SNA-Simposium Nasional Akuntansi 12: 131

Rieckhof, R., A. Bergmann, dan E. Guenther. 2015. Interrelating Material Flow Cost Accounting with Management Control Systems to Introduce Resource Efficiency into Strategy. Journal of Cleaner Production 108(2015): 1262-1278.
Riwayadi. 2014. Akuntansi Biaya. Salemba Empat. Jakarta.

Rustika, N. 2011. Analisis Pengaruh Penerapan Akuntansi Manajemen Lingkungan dan Strategi Terhadap Inovasi Perusahaan (Perusahaan Manufaktur yang Terdapat di Jawa Tengah). Jurnal Ilmiah 2(1): 1-13.

Putranto, A. 2017. Analisis Pengaruh Biaya Produksi dan Penjualan terhadap Laba Perusahaan (Studi pada Usaha Mikro Kecil dan Menengah di Kecamatan Wonosobo Kabupaten wonosobo). Jurnal Penelitian dan Pengabdian Kepada Masyarakat UNSIQ 4(3): 280-286.

Putra, R. E. 2012. Pengaruh Nilai Investasi, Nilai Upah, dan Nilai Produksi terhadap Penyerapan Tenaga Kerja pada Industri Mebel di Kecamatan Pedurungan Kota Semarang. Economics Development Analysis Journal 1(2).

Setiawan, T. 2016. Penerapan Akuntansi Manajemen Lingkungan pada Dua Puluh Lima Perusahaan yang Terdaftar di Indeks Sri Kehati 2013. Jurnal Akuntansi 9(2): 110-129.

Siregar, I., Lindrianasari, dan Komaruddin. 2013. Hubungan Antara Kinerja Lingkungan Dan Kinerja Komite Audit Dengan Kualitas Pengungkapan Corporate Social Responsibility (Pada Perusahaan Mamufaktur Di BEI). JURNAL Akuntansi \& Keuangan 4(1): 6381.

Susilo, J. dan N. Astuti. 2014. Penyusunan Model Green Accounting untuk Perusahaan melalui Perhatian, Keterlibatan, Pelaporan Akuntansi Lingkungan dan Auditnya. Permana 5(2): 17-32.

Sugiyono. 2012. Metode Penelitian Kuantitatif dan Kualitatif RED. Alfabeta Bandung. Bandung.

Tajelawi, O. A. dan H. L. Garbharran. 2015. MFCA: An Environmental Management Accounting Technique for Optimal Resource Efficiency in Production Processes. International Scholarly and Scientific Research \& Innovation 9(11): 3699-3704. 
Tarigan, J. dan R. H. Semuel. 2014. Pengungkapan Sustanability dan Kinerja Keuangan. Jurnal Akuntansi dan Keuangan 16(2): 88-101.

Tarmizi, R., D. Octavianti, dan C. Anwar. 2012. Analisis Pengungkapan Akuntansi Lingkungan terhadap Pertanggung Jawaban Sosial Industri Kimia (Studi Kasus pada Sosial Industri Kimia di Kota Bandar Lampung. Jurnal Akuntansi E Keuangan 3(1): 21-38.
Viere, T., A. Mollerand, dan M. Prox. 2011. Material Flow Cost Accounting Approach to Improvement Assessment in LCA. International Journal for Sustainable Innovations 1(1): 1-7.

Winarno, W. A. 2016. Corporate Social Responsibility: Pengungkapan Biaya Lingkungan. Jurnal Akuntansi Universitas Jember: 73-88. 